UDC 658.114: 330.322

JEL Classification: M40

http://doi.org/10.21272/mmi.2019.3-17

Marius Ciubotariu,

Ph.D., Lecturer, Stefan cel Mare University, Romania

Marian Socoliuc,

Ph.D., Lecturer, Stefan cel Mare University, Romania

Svetlana Mihaila,

Ph.D., Associate Professor, Academy of Economic Studies of Moldova, Republic of Moldova

Dmytro Savchuk,

Ph.D., Associate Professor, Yuriy Fedkovych Chernivtsi National University, Ukraine

\title{
COMPANIES IMAGE: MARKETING AND FINANCIAL COMMUNICATIONS
}

Abstract. The main purpose of the study is to evaluate the quality of the economic and financial data from the point of view of satisfying the shareholders' demands as well as of the influences that the structure of the shareholding can have on a company's economic and financial informational system. The bases for the theoretical background were a systematic overview and a critical analysis of the literature from the study field. According to the findings from the literature study, links were developed between the study areas and a hypothesis of the relationship between the state's status as a stakeholder and the quality of the information that was published in the annual reports. The analysed sample initially was made up of those companies (105) that were listed on the Stock Market of Bucharest whereas the evaluation method of the quality of disclosure was based on the scoring method, i.e. the scoring points that are given to the classified elements, the nature of the simple or derivative indicators. After applying the inclusion and exclusion criteria remained only 65 of the company. The object of research is the companies that prepare their financial reports using the IFRS reference (International Financial Reporting Standards). The main information sources were the annual or interim published financial reports. This paper shows that economic and financial communication needs to make improvements in terms of the informational transparency that is a key element for building up its credibility. Even if the study's practical examples focussed only on the stakeholders' demands, the quality of the economic and financial disclosure requires that the supplied information has all those features that characterize high-quality information, that is the must be relevant and precise, easy to understand, timely, comparable and verifiable. The importance of the present study results from the fact that the beneficiaries of financial information are becoming more and more interested in quality information, a characteristic that is basically the foundation of their decisions in regards to the reporting entity. The results of the study may be useful to the stakeholders, the business environment, the financial-banking institutions, the state, highlighting the importance, need and benefits of a qualitative economic and financial communication in the decision-making process.

Keywords: economic information, financial information, indicators, quality, scoring, shareholding.

Introduction. Generally speaking, the information system can be defined as a company's subsystem that obviously refers to the adhering part of the data that were gathered, processed and produced (Monteduro\&Salemo, 2011). The informational system is basically a sum of those elements that contribute to the gathering, changing and activating the data in order to produce and supply this information to certain individuals that work on different levels within a company. The specialty literature has indicated the fact that this kind of system is made up of the following elements: a data basis, a group of procedures that are necessary for obtaining and processing the data in order to generate information, an ensemble of methods that enable data transfer, a system that enables the data and information storage, a group of general guidelines, values and reasoning's that characterize the system itself and determines the entity's behaviour in regards to the inside and outside world.

The speciality literature also conveys the fact that the information system of an economic entity can be broken down into three subsystems such as:

Cite as: Ciubotariu, M., Socoliuc, M., Mihaila, S., Savchuk, D. (2019). Companies Image: Marketing and Financial Communications. Marketing and Management of Innovations, 3, 223-241. http://doi.org/10.21272/mmi.2019.3-17 
- The Electronic Data Processing System - EDP focuses on substituting certain activities that take place in a company. It is important for sustaining a vast majority of the operational activities;

- The Management Information System - MIS focuses on generating the current information that is necessary for controlling and programming the company's activities. It functions as a support system for the planning and financial management control;

- The Decision Support System - DSS that is used for the less significant unpredictable decisions and responds to the company's needs based on information deriving from the instant decisional activities.

The information systems that are specific to the reporting entities are, in their turn, made up of two complementary components (Marchi, 1993) such as the public (official) information system and the private (individual) information system.

The public system is developed by the companies' management team and refers to the mandatory information supplied by them. Apart from this system, the vast majority of the companies (based on the initiative of certain individuals from the company) are interested in developing an information system that acts as a support for implementing the decisions of a single person or of a small group of individuals. In the large companies, the information system is much more complex and it needs to be analysed sequentially on the stages of its usage. Thus, a clear distinction needs to be made in regards to management and informational system and the operational and informational system which, in its turn, is divided into certain functional areas it refers to.

One can argue that the informational system stands for a system of changes (Mancini \&Lamboglia, 2005) as one witness the data processing (i.e. the input factors) in the form of information (i.e. informational output) that stands for its final product. In order to obtain some efficient informational systems, the companies need to design carefully these databases so as they are as attractive as possible. Data collection follows a prior identification plan which means identifying those activities that need to be observed. They are the study's objectives and analysis fields. The data will be further selected in order to discard the useless ones and to classify them based on pre-established criteria. Their classification represents the first stage in designing the informational system and may be equivalent to identifying the common features of the activity, its accomplishment being necessary for building up more classes and homogenous groups that refer to certain classification criteria. Data collection, selection, classification and development represent an ensemble of activities that altogether have the communication as a common target. In its turn, in order to be as much efficient and quick as possible, it makes use of encoding.

The goal of our study is both based on evaluating the quality of the economic and financial information form the point of view of satisfying the shareholders' demands and on the influence of the shareholding structure can have on the company's economic and financial informational system. The objectives that lay the foundation for this specific purpose refer to the identification of the types of information that are supplied and produced by the informational economic and financial system and the evaluation of the quality of this information in relation to the shareholders from the point of view of satisfying the demands of the involved parties. The importance of the theme results both from the very scope of improving or optimizing the relationships that exist between the management of a company and its shareholders and the influences of the structure of the shareholding itself.

Literature Review. The economic and financial communication target needs to be connected with the one of the enterprises, namely it needs to be focused on the idea of «self-generating in time» based on increasing in value. This approach represents the way an organization manages to develop its own systems and, at the same time, to supply and generate economic value in its relationships with the outside world. Thus, the overall objective may be defined as finding a balance and a connection with the exterior environment. Cocozza (2006) states that in spite of the fact that in a short period of time those 
companies that innovate their own culture so that their values correspond to the shareholders' demands can be penalized, in the long run, they will manage to adopt reconsolidation and socialization procedures in agreement with the new values. This will enable the company to become more competitive and to experience the growth of its goodwill in relation to the parties involved. From this point of view, sharing and creating value takes place as a result of assimilating the (enterprise's) offer to the (reference market's) demand based on communication. From this point of view, the economic and financial information are the key elements for the relationship between the company and the investors of credit capital and risk capital. Sharing and internalizing the values mean a commitment, the company's continuous and long effort that is emphasized by all the actions that are initiated throughout time. From this point of view, Fiocca (2002) has reported eight steps that illustrate the process of designing and distribution of corporate values based on efficient communication. A certain type of corporate values specifies the means through which certain types of variables seem to be very powerful in themselves. Fiocca believes that the values of a company accumulate due to the presence of the disclosure and the organizational processes that lead throughout time to a learning and acting way that contributes to the development of certain characteristics such as culture, identity and different types of abilities. In the event that all these characteristics are prone to an innovation process, success may be experienced (this is how the self-identification will take place) which, in its turn, will likely consolidate the company's values.

The economic and financial disclosure has taken on great importance in regards to two key factors. The expansion of the number and the typology of the enterprise's partners shows the way the economic success depends on both the stakeholders' legitimacy and the need to allocate a large number of external resources to meet the same target (Corvi, 2000; Nastase et al., 2010).

Thus, disclosure has a well-defined role of clearly emphasizing the company's ability to construct a credible strategic image for itself, more exactly to generate revenue, trust and legitimacy. One basically has in view building up an extremely external positive point of view in regards to one's self-image. This point of view is based on the company's past way of conducting business and on its future perspectives of development by becoming a more efficient tool in influencing the outside stakeholders' decisions based on the company's ability to meet these stakeholders' demands and needs.

Thus, it is obvious that the economic and financial disclosure is not only a means of dissemination of information but also a tool for defining the company's image in order to create a competitive advantage. The relationship that the company has established with certain categories of stakeholders has become useful for transferring the coordination process and the existing collaborations within this company. It has become a well-known fact that an enterprise is a sum of several resources. The collaboration and the coordination of these resources are a clear indication of the ability to reach the pre-established objectives and of generating economic value (Cosmulese, 2015). The roles of the internal and external disclosure are different. The role of the internal disclosure is to develop the cohesion between the parties, whereas the external disclosure acts as a contact link with the environment in which it manifests itself by enabling the company's development and the dissemination of its values, of the abilities and of the culture (Bostan, Grosu\&lancu, 2009). It is essential that any company develop its relationship with the stakeholders in order to disclose or report the value. There are studies that have shown the fact that the disclosure that is based on a clear, apprehensible and verifiable explanation of the actual information that is presented on the market contributes significantly to the creation of value and, consequently, to the growth of the company's assets (Di Gaspare, 2011).

The immediate effect is shown by the company's image as one of the disclosure's key element that is able to make the company's objective or book value coincide with the market value (Grosu, 2013 ). During the creation and dissemination of value, the company's intangible resources have a key and wellknown role. The idea behind the intangible assets is that in a company there are capacities or resources 
that do not have a concrete representation, such as the technical knowledge or the business culture (Corvi, 2007; Grosu, 2010; Mot et al., 2014; Burciu\&Kicsi, 2015; Cosmulese et al., 2016; Cosmulese, 2017). These are resources that are difficult to separate from another active support, namely to be individually identified due to the fact that they are based on the knowledge and the information that the company has in order to achieve its desired targets based on the consumers' trust, the company's image, its brand or the management's abilities. They represent, in fact, the enterprises' main source of competitively. The intangible assets are defined as those resources that rely on a piece of information or those information they incorporate (Itami, 1998 ), whereas the management of the intangible assets in the government sector becomes more important due to the improvement of the internal performance such as the management control (Bunget et al., 2014). Each and every economic and financial disclosure policy is influenced by that information that is received from the outside world as together with the stakeholders' evolution and demands its target is to adapt the company's behaviour and attitude based on their own interests.

Methodology and research methods. In order to achieve the target results, our research needed to focus on 105 companies that were quoted at the Stock Market of Bucharest (SMB). The main information sources were the annual or interim published financial reports. The testing of the relevance of the information corresponding to the simple or derivative financial indicators that were calculated or taken from the financial statements was done by using the SPSS program. An important factor that we had in mind for the selection of these companies was the fact that all these companies prepare their financial reports using the IFRS reference (International Financial Reporting Standards) which guarantees in the reasonable proportion both the data comparison and their credibility on a national and international level. From this point of view, the following set of assumptions were formulated:

1st Assumption: There is a positive relationship between the state's status as a stakeholder and the quality of the information that was published in the annual reports;

2nd Assumption: There is a negative relationship between the percentage of stakeholders as individuals and the quality of information that was published in the annual reports.

In order to achieve the target of the research, we focused on the scoring method based on scoring points that were given to those classified elements based on the nature of the simple or derivative elements that were afferent to the mandatory financial reporting.

Regarding the identification of the types of information supplied by the informational system we need to emphasize the fact that the data presentation and exchange are essential for a company's economic activity. They are able to "make the connection" among different components within the organizational framework. Generating information, like any type of an organizational process, refers to data collecting (i.e. the process input) and their transformation finalizes itself with gathering the data (i.e. the process output). The latter are used within the company (in order to support the decision-making process) or are made known outside the company. The figure given below shows the stages of generating financial and economic information:

In this context, the information system gains a double representation:

- internal representation that addresses to the companies various functional levels that support the decision-making process during different moments or specific stages of business administration;

- external representation that enables the communication outside the company based on the information that refer both to the company's position and financial performance and its future development opportunities. 


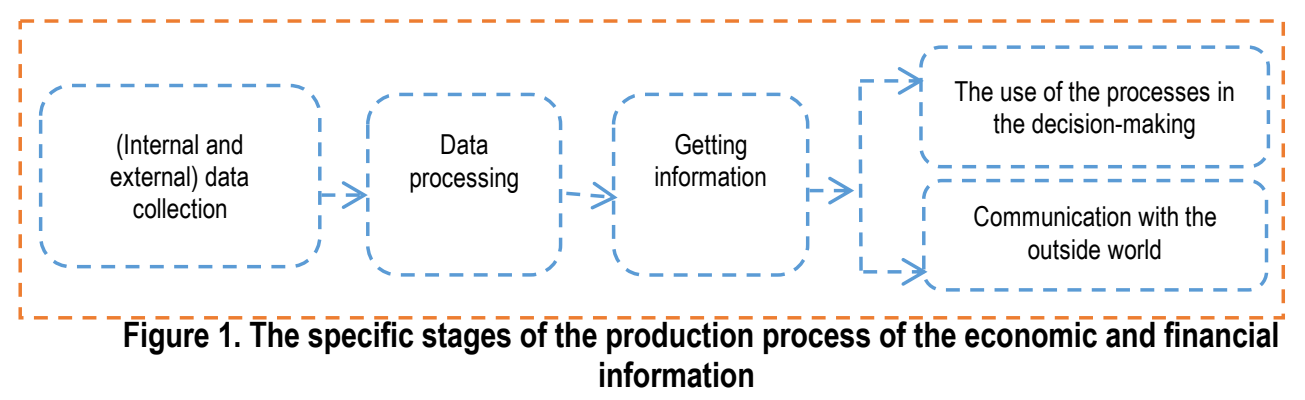

Source: personal interpretation.

Thus, the objective of the informational system of a company refers to supplying (simultaneous or future) useful and timely information in order to solve the management and organizational issues. In their turn, the financial and economic information may be either quantitative that, as a rule, are expressed through numerical values, or non-quantitative that are collected based on the actual observation, on interviews, on issues from articles and magazines etc. The figure below shows their graphical representation:

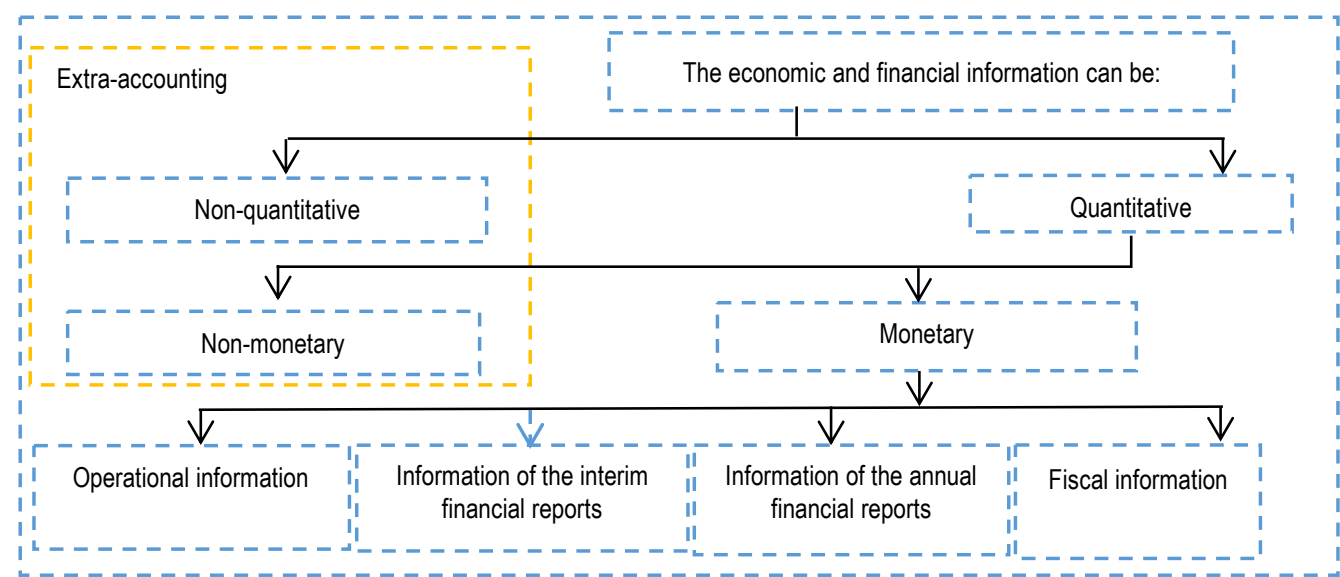

Figure 2. Types of economic and financial information that were reported by companies

Source: adapted from the Accounting, Anthony et al, (2005).

In regards to the quantitative information, they are made of two categories such as: monetary (economic and financial) information and non-monetary (physical and technical) information that cannot basically be expressed in monetary terms. The physical and technical are non-quantitative and are a sub-category of the extra-accounting information in spite of the fact that the accounting informational systems are mainly expressed by the quantitative information, especially through the monetary information. As shown in Figure 2, there are several types of economic and financial information that are reported by companies such as:

1. Operational information that are necessary to enable the development of the companies basic operations (e.g. the paid salaries, information on products for sale, costs, selling costs etc.);

2. Balance sheet information that are used either by the management team, or by other third parties (internal and external stakeholders that are interested by the company's economic situation); 
3. Fiscal information: the companies need to possess information that need to be used to determine the profit or other types of information regarding taxes; 4.other information that result from the (internal) management are those information of a different nature that the managers use to configure their own objectives, strategies and decisions.

Regarding the quality of the informational system within the present economic situation and its relationship with the structure of the shareholding, we can affirm that the recent financial scandals have shown that the accounting fraud risk can be disseminated in any type of economic system. In this given context, the informational transparency, an essential element for the competitiveness of a company within the market it operates, requires an efficient running of the corporate governance systems especially of the internal checking system. It is mandatory for all these aspects to follow the existing guidelines in regards to the external reporting. The governance issue needs to be considered as a key element against those pressure leading to committing a fraud, an aspect that is influenced by the lack of informational transparency.

In this context, the institutional communication represents both a synthesis and the Corporate Identity support (or the global and relational strategic orientation) throughout time that contributes to the formation of the corporate reputation. According to this communication concept, its recipients or beneficiaries are represented by all the categories of stakeholders. Its objective is geared towards qualifying the company as an «institution» both in its operating environment and in the social one in order to become legit and to be favored both in everyday situations and in crisis situations. In regards to characterizing the organizational control, this is made up of the management of the external relationships (i.e. staff management). The most frequently used communication methods are the PR (Public Relation) and advertising. A distict representation of the mechanism of the institutional communication was shown by Pastore\&Vernuccio (2008) in the figure below:

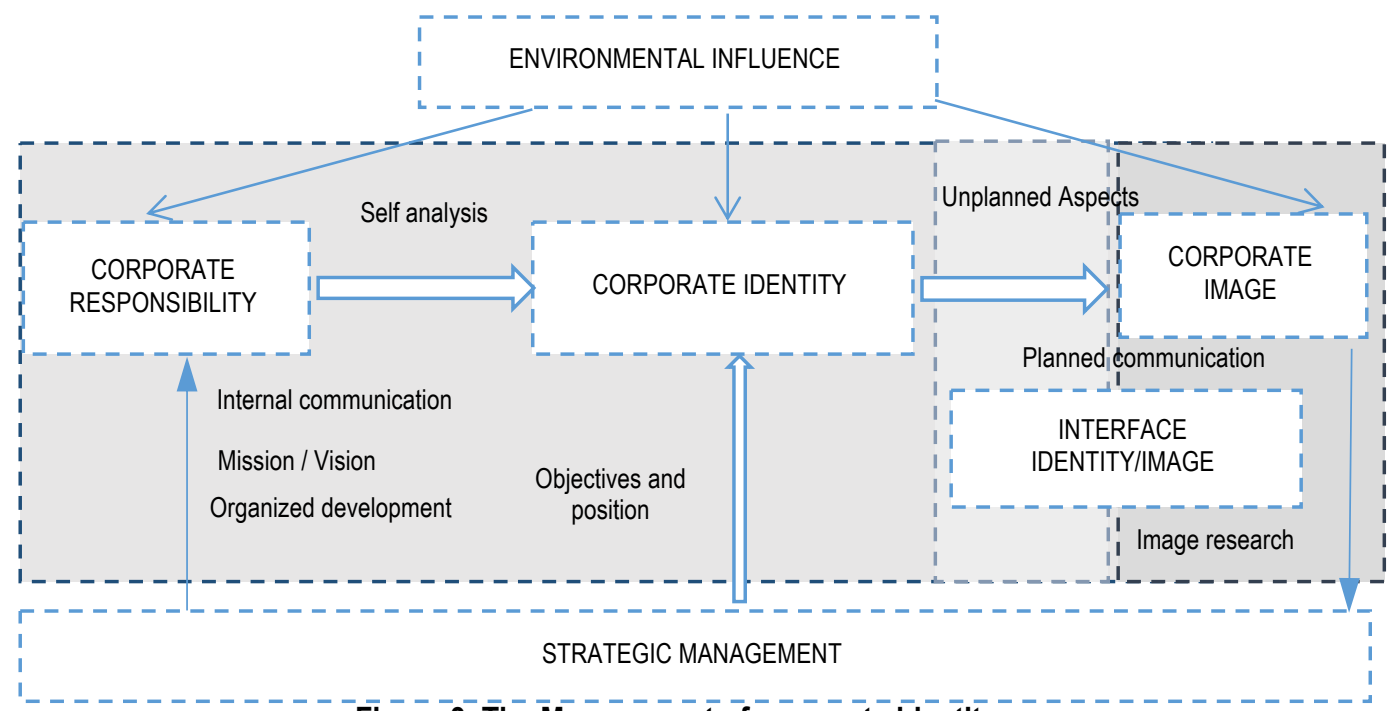

Figure 3. The Management of corporate identity

Source: adapted from the Impresa e comunucazione, Pastore \& Vernuccio (2008).

The group representation of a company's past actions and the future perspectives describe the way the owners of critical resources interpret the enterprise's proposals that will serve as a foundation in analyzing its ability to satisfy its own demands (Van Riel\&Fombrun, 2007). The use of the institutional 
communication refers first and foremost to public affairs and lobbying crisis communication, the social communication, the environmental communication and cultural communication. The same authors mentioned above (Pastore\&Vemucio, 2008) have succeeded in synthesizing the key elements and the main indicators of this type of communication that are shown in the representation provided below:

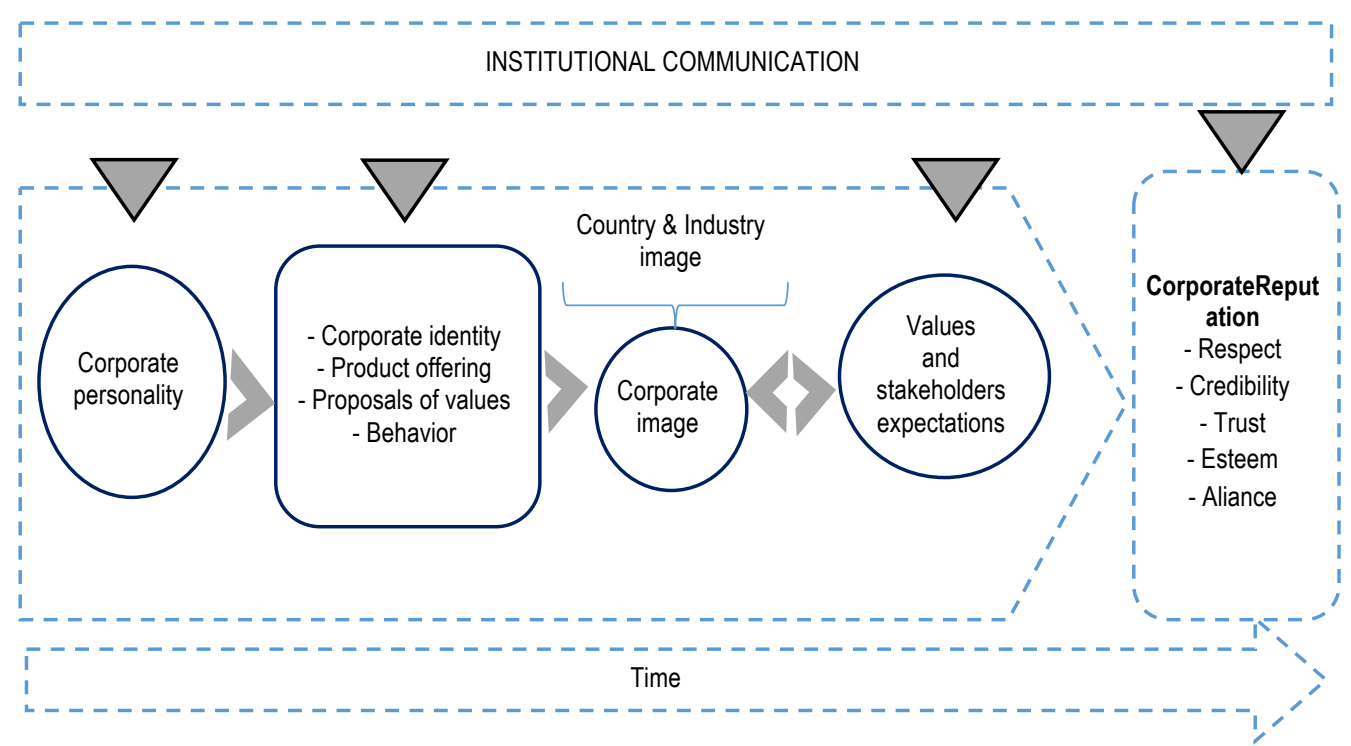

Figure 4. The support for the Corporate Reputation based on the institutional communication

Source: adapted from the Impresa e comunucazione, Pastore \& Vernuccio (2008).

The specialty literature lacks a rigorous definition of the accounting fraud. This is the reason why a distinction between the fraud that is caused by the "management's pressures» and the ones that are as a result of the «pressures on the result» needs to be made.

A comparative study of the main American and European scandals seems to confirm the significance of these two types of frauds. The empirical analysis allows the checking, on the one hand, of its origin and the development of the frauds and, on the other hand, the close relationship between the corporate governance and the types of frauds. In all the corporate governance models, the external provision has a key role in guaranteeing the efficiency of the internal checking systems. In all the corporate governance models, the external provision has an important role in ensuring the efficiency of the internal control systems. Nevertheless, the companies are fully responsible for the adoption of that particular type of mechanism that is able to provide the quality of information. A case in point are the multinational companies that have made the connection between their national legislation and those tools that are specific to the implemented governance models. The markets' evolution and globalization, the financial scandals that have led to the downfall of the economies in North America and Europe, the growing pressure of the stakeholders on the economic performance are some of the factors that have stirred intense debates on the the key role of the economic and financial disclosure and the growing importance taken on by the corporate governances within the present worldwide context (Lacchini, 2002). The main advantage of the system of corporate governance is the growth of the management performance that refers to attracting new investors. This will result in the company's sustainable development and in a better management of the operational risks. Taking into account the fact that one of the features of the financial market is having a so called «virtual inheritance» the moment a financial 
product is offered to the general public. «The inherent information for building up this inheritance is consequently offered as such» (Bocchini, 2001). Thus, the content, the quality and the efficiency of the governance systems for which the control plays an essential role, stand for the key elements in ensuring the optimum supply of the market resources. This is the reason why the legislative bodies need to focus primarily on regulating the markets where the companies do their business. At the same time, the external information is viewed as playing a key role for the proper development and functioning of the financial markets. This thing allows these type of information to gradually become more accessible based on the dematerialization and globalization of the informational processes (Poggio, Zaccone \& Bianchi,2003). In this context, the impact of the financial and economic information has grown requiring a larger number of stakeholders or other users of economic and financial information who have different interests. Their demands have led to an exponential growth of the pressure on the companies in terms of the «target results». The external information is, thus, placed in the centre of the ensemble of relations among companies and the large and heterogenous variety of stakeholders that characterized by different interests and targets(Salvioni, 2002). In our opinion, they have a key role in the balanced development of the companies that depend on the availability and the optimum allocation of the financial resources that are necessary for the process of creating competitive advantages and to generate profits. The financial markets actually represent the main access channel to these kinds of resources by representing, at the same time, an indispensable element for the development of the companies and of the economic systems.

From this point of view, the economic and financial communication facilitates the right orientation of the internal behaviours and of the management activity based on the performance and the external consensus in order to restore the (resources') risk and borrowed capital. The close relationship between the available information and the stakeholders' decision - making process lies at the basis of the growing importance of the information whose key role as a fundamental variable in influencing the investment decisions is acknowledged by all companies. Thus, the informational system is influenced by a series of variables that can have an impact on the quality of the information supplied by them as in the figure shown below:

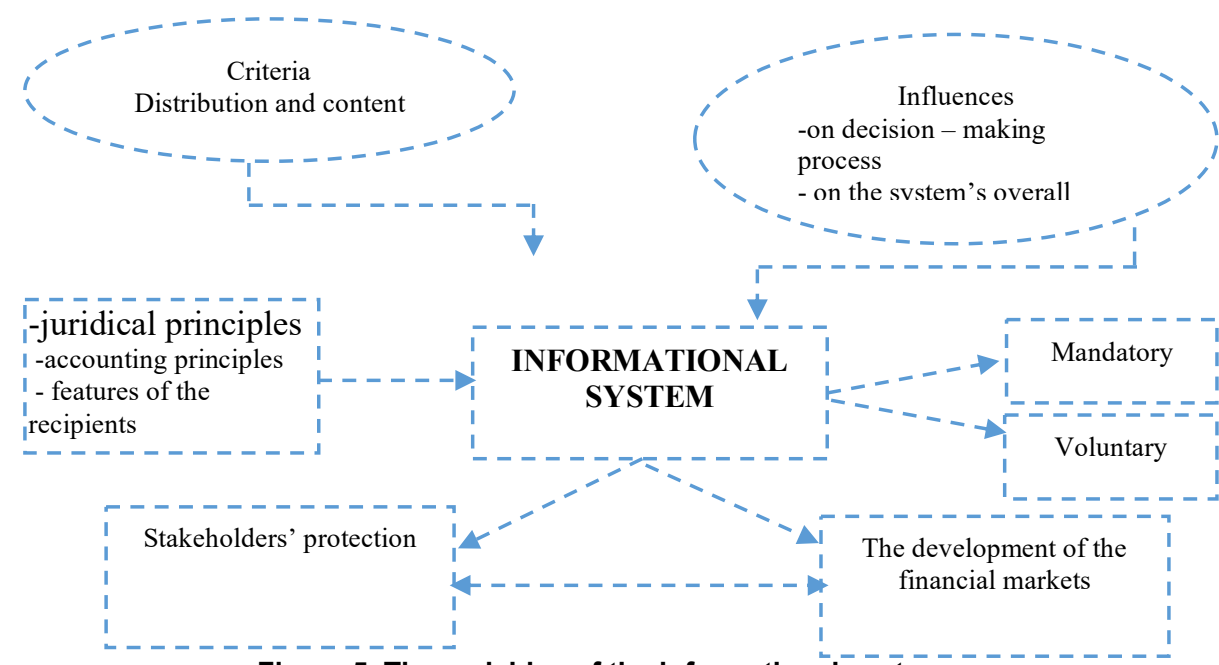

Figure 5 . The variables of the informational system

Source: personal interpretation. 
Within a well-developed economy, the access on the market means the remake of the risk resources that are necessary for maintaining the competitive advantages. The success of those companies that activate on the financial market is increasing. They are dependent on the management of the relationships with their stakeholders as well as on the information offered to them. In accomplishing the objectives in the growth of the capital and the performance of the activity, the results can be satisfactory only if they are accompanied by their correct transparency and reporting on the market (Cuervo, 2002). The companies' ability of getting the necessary agreement of the stakeholders and the necessary resources depend not only on the economic performance but also on:

- The sharing of informations that are geared towards facilitating the evaluation processes;

- The accurate selection of the content, the type and communication methods of the messages in regards to the existing requirements and the interests of different types of users.

The efficiency of the management of the economic activity thus depends on the support that is offered through sharing the internal and external information. In order to attain the management objectives, the internal information are mainly used while the external information are geared towards satisfying the demands of different categories of stakeholders. As for the communication processes that are based on maintaining the economic efficiency, the economic and financial messages play a key role. By making use of the economic and financial information system, a company presents the efficiency and effectiveness degree that has been accomplished throughout its activity based on sharing those relevant useful and selective information that focus on expressing symbolically those complex phenomena and the «results» of a vast number of relationships.

Nevertheless, the shared information allow the operators from the financial market to formulate opinions on the means of developing the future economic activity. These opinions are the foundation of the trust that the market guarantees these companies. The economic and financial communication is fully responsible for the trend related to the internal behaviours by this leading to qualitative and quantitative resources that are able to satisfy the company's demands (Spaventa, 2002). As a result of the growth of the relevance of the economic and financial information regarding the global efficiency of the economic system, the pressure of the stakeholders on the company rises, too, by enhancing the governance and control difficulties of the informational affluence caused by them. A case in point is The International Financial Reporting Standards that in the past few years have clearly shown the key role of the information itself especially of the damages caused within the economic system and within each and every company as a result of a poor briefing or of certain inaccurate, uncontrolled and unchecked information.

The stakeholders' positive expectations are essential for the company's survival. The attainment of their expectations becomes a priority that equals with the initial objectives regarding the management of the company's activity. According to the international literature in this field, the likelihood of sustaining the conditions of an economic success depends on: the perception of the different agents' expectations on the market; the likelihood of controlling the messages geared towards facilitating the degree of satisfaction of these expectations; the likelihood of establishing a trustful relationship with the business people and the accurate management of the external consensus; the markets' globalization and the shortening of the reporting processes by further focussing on the importance of the communication models for activating certain positive relationships between the external environment and the company itself.

The measurement of the quality of the economic and financial communication as part of the annual reporting is based on two main approaches. The first approach refers to a broad usage of the so-called content analysis that is a research method based on the observations on the systematic evaluation of the content of the supplied information (Kassarjian, 1997). This technique allows a variable deduction of the data to be made based on their content. The analysis of the content of the financial situations based 
on pre-established criteria (Marston \& Shrives, 1991) and of the collected data (that are shown in qualitative codes of the information from the literary texts) are turned into categories or classes of information that focus on getting quantitative levels that measure different degrees of disclosure.

Based on the type of approach in the international literature regarding the measurement of the quality level of the economic and financial information from the annual reports, they can be summarized as shown in the below figure:

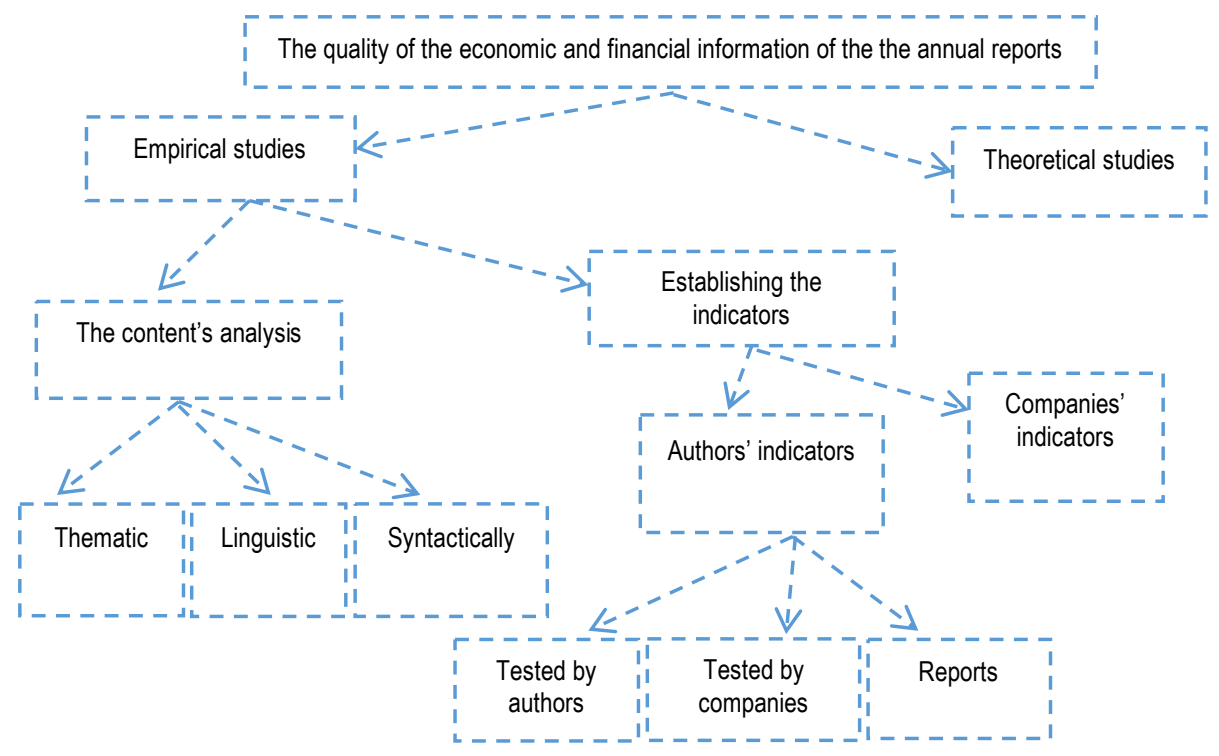

Figure 6. The quality of the economic and financial information that are part of the annual financial statements and of the annual reports

Source: Adapted after Jetty \& Beattie (2009).

The 2nd approach that has been accepted by the majority of the members of the international scientific group relies on those indicators that are able to evaluate, compare and explain the differences that manifest when using the economic and financial information of the annual reports.

The structure of the shareholding and its impact on the quality of the economic and financial disclosure

The structure of the shareholding can have either a positive or a negative influence on the quality of the financial-accounting disclosure. Some authors like Adhikari\&Tondkar (1992) have shown that the structure of the shareholding has a significant influence on the way the companies share the information. The differences regarding the disclosure of the information from the annual reports between those stateowned companies in comparison with those publicly owned companies were identified by El-Issa (1998). Some authors (El-Issa, 1998; Djoko, 1992) have shown that the financial reporting and the quality of the communication within the state-owned companies is poor in the under developed countries. Yet, there is a positive relationship between the degree of public ownership and the companies' degree of disclosure. In spite of the fact that the concentration of the companies'capital can be a guarantee of efficiency, most of the researchers have not noticed in their studies a positive impact on the quality of the disclosure of information. The family businesses or the ones managed by a single owner are less transparent and are not willing to disclose information voluntarily. In a study that was done on 98 companies in Hong Kong 
by Ho\&Wong (2001) the consequence of dispersing the capital on the level of disclosing voluntary information was analyzed. The authors have shown that the companies that have a concentration of capital, its management team will not be willing to disclose voluntary information. Another study, such of the one of Labelle \& Schatt (2005) has shown that within the companies where the stakeholders are less present, the management team is more inclined to enrich the quality of the financial disclosure.

Based on the previous researches, our study will focus on testing in this particular case, the existence of a relationship between the quality of the economic and accounting disclosure and the state as a stakeholder. Moreover, we will study the possible connection between the percentage of stakeholders as individuals and the quality of the financial and accounting disclosure. In order to be able to test the assumptions below, we started by emphasizing the existence of the three types of stakeholders (the state as a stakeholder, the stakeholders as individuals and legal persons) and by estimating the percentages corresponding to each and every category (Table1).

Table 1. The companies' distribution on sectors of activities

\begin{tabular}{|c|c|c|c|c|c|}
\hline Sector & $\begin{array}{c}\text { No. of listed } \\
\text { companies }\end{array}$ & \begin{tabular}{|c|} 
Stock exchange \\
capitalisation per \\
branch
\end{tabular} & $\begin{array}{l}\text { The weighting } \\
\text { of the total } \\
\text { capitalisation }\end{array}$ & On-site assets & $\begin{array}{l}\text { The weighting } \\
\text { of the on-site } \\
\text { total assets }\end{array}$ \\
\hline I. Mining & 3 & $26,774,447,044.80$ & $20.01 \%$ & $23,164,758,512.00$ & $29.43 \%$ \\
\hline $\begin{array}{l}\text { II. } \begin{array}{l}\text { Products of the manufacturing } \\
\text { industry }\end{array} \\
\text { in }\end{array}$ & 43 & $5,894,843,339.00$ & $4.40 \%$ & $4,985,419,998.00$ & $6.33 \%$ \\
\hline III. Electricity and heat, gas şi water & 1 & $1,157,456,612.18$ & $0.86 \%$ & $2,430,055,959.00$ & $3.09 \%$ \\
\hline IV. $\quad$ Constructions & 6 & $251,032,117.50$ & $0.19 \%$ & $761,167,981.00$ & $0.97 \%$ \\
\hline $\begin{array}{ll}\text { V. } & \text { Wholesale and retail trade, the } \\
\text { vehicles', personal belongings' and } \\
\text { appliances' mending }\end{array}$ & 4 & $249,385,554.64$ & $0.19 \%$ & $231,218,497.00$ & $0.29 \%$ \\
\hline VI. Hotels and restaurants & 4 & $173,297,480.46$ & $0.13 \%$ & $498,042,773.00$ & $0.63 \%$ \\
\hline \begin{tabular}{l|l} 
VII. & $\begin{array}{l}\text { Transportation, storage and } \\
\text { communications }\end{array}$
\end{tabular} & 4 & $2,697,551,208.83$ & $2.02 \%$ & $4,046,078,006.00$ & $5.14 \%$ \\
\hline $\begin{array}{l}\text { Total number of fields of activity } \\
\text { comprised by the sample }\end{array}$ & 65 & $37,198,013,357.41$ & $27.80 \%$ & $36,116,741,726.00$ & $45.89 \%$ \\
\hline $\begin{array}{l}\text { Total on the market level not included in } \\
\text { the sample }\end{array}$ & - & $96,631,693,708.43$ & $72.20 \%$ & $42,582,596,479.00$ & $54.11 \%$ \\
\hline Total on the market level & - & $133,829,707,065.84$ & $100.00 \%$ & $78,699,338,205.00$ & $100.00 \%$ \\
\hline
\end{tabular}

1st Assumption: There is a positive relationship between the presence of the state as a stakeholder and the quality of the information that is published in the annual reports.

2nd Assumption: There is a negative relationship between the percentage of stakeholders as individuals and the quality of the information that is published in the annual reports.

The reference sample for our study comprises all the listed companies in the Stock Market of Bucharest. There were 105 companies at the end of 2018. When we chose this sample, we had in mind the following aspects:

- the companies are listed on a regulated market;

- the transparency that the companies need to show regarding their activity based on the disclosure process;

- the size of the company and the diversity of their fields of activity.

The companies that belong to our sample are grouped in six categories in the Stock Market of Bucharest according to table 2 given below. 
Table 2. The categories of companies listed on the Stock Market of Bucharest

\begin{tabular}{|c|c|c|}
\hline Category & No. of companies & Percentage out of total \\
\hline I & 28 & $26.67 \%$ \\
\hline II & 52 & $49.53 \%$ \\
\hline III & 1 & $0.95 \%$ \\
\hline International & 1 & $0.95 \%$ \\
\hline Others & 1 & $0.95 \%$ \\
\hline Unlisted & 22 & $20.95 \%$ \\
\hline TOTAL & 105 & $100.00 \%$ \\
\hline
\end{tabular}

Source: personal interpretation.

Out of the total companies that we started from in our research, the financial institutions (the banks, the insurance companies, the investment funds etc.), the international companies, the unlisted companies and two companies that were delisted during 2014 were rejected based on their specific reporting.

Later on, as a result of browsing the websites of those 68 companies of the sample, we noticed that in the case of two companies the annual report for 2014 could not be found on the site of the Stock Market for 2014 or on their own web-site. The web-site of one company could not be accessed. This led to their rejection from the sample.

Table 3 briefly shows those companies that were included and those that were rejected from the research sample.

Table 3. The summary of those companies that were included and those that were rejected from the research sample

\begin{tabular}{|l|c|c|}
\hline \multicolumn{1}{|c|}{ Type of business } & $\begin{array}{c}\text { No. of } \\
\text { businesses }\end{array}$ & $\begin{array}{c}\text { Percentage of the total } \\
\text { no. of companies }\end{array}$ \\
\hline 1. Companies from the researched sample & 65 & $61.90 \%$ \\
\hline $\begin{array}{l}\text { 2. Companies rejected from the research sample out of } \\
\text { which: }\end{array}$ & 40 & $38.10 \%$ \\
\hline $\begin{array}{l}\text { 2.1. Financial institutions(banks, insurance companies, } \\
\text { investment funds etc.) }\end{array}$ & 11 & $10.48 \%$ \\
\hline 2.2. International companies & 2 & $1.90 \%$ \\
\hline 2.3. Unlisted & 22 & $20.96 \%$ \\
\hline 2.4. Delisted in 2014 & 2 & $1.90 \%$ \\
\hline 2.5. Unavailable annual reports & 3 & $2.86 \%$ \\
\hline \multicolumn{1}{|c|}{ TOTAL } & 105 & $100.00 \%$ \\
\hline
\end{tabular}

Source: personal interpretation.

Results. The indicators that were selected by us for testing the assumptions regarding the Shareholding's structure are the following: the state as a stakeholder and the majority of the stakeholders as individuals. We will then test the normality of the distribution of the variable of the Shareholding' structure. We will provide a diagnosis and we will provide a normality procedure Table 4.

The histograms that have been created after the normality of the distribution of the variable entitled Shareholding's structure (The state's presence in the shareholding's structure and the full representation of the stakeholders as individuals) can be found in Table 5 . 
Table 4. The result of testing the assumptions regarding the Shareholding structure

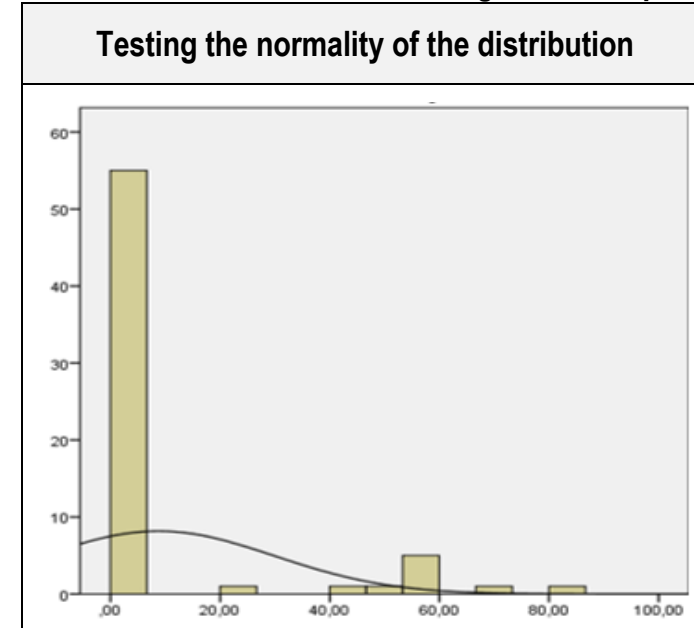

Figure 7. The presence of the state in the shareholding's structure

\begin{tabular}{|c|c|c|}
\hline \multicolumn{3}{|c|}{ The Kolmogorov-Smirnov test } \\
\hline Statistical & $\mathrm{df}$ & Sig. \\
\hline 0,457 & 46 & 0,000 \\
\hline
\end{tabular}

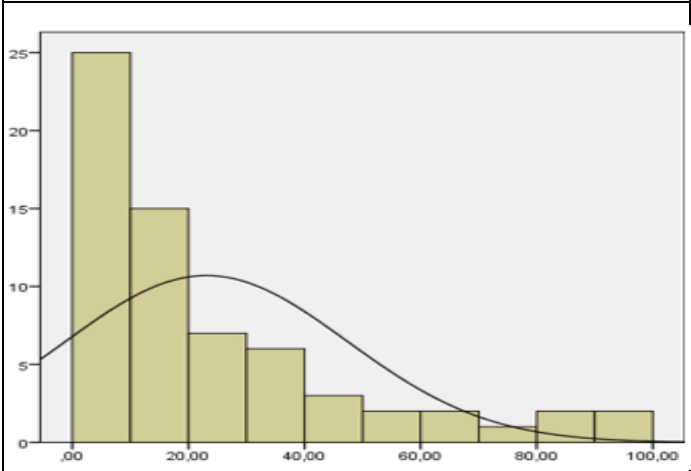

Figure 8. The presence of the individuals in the shareholding's structure

The Kolmogorov-Smirnov test

\begin{tabular}{|c|c|c|}
\hline Statistical & df & Sig. \\
\hline 0,209 & 46 & 0,000 \\
\hline
\end{tabular}

\begin{tabular}{|c|c|}
\hline Diagnosis & $\begin{array}{c}\text { The normality } \\
\text { procedure }\end{array}$ \\
\hline $\begin{array}{l}\text { Based on the histogram } \\
\text { shown herewith, the } \\
\text { variable entitled The } \\
\text { presence of the state in } \\
\text { the shareholding's } \\
\text { structure has a marked } \\
\text { positive assymetry. } \\
\text { Moreover, the } \\
\text { Kolmogorov-Smirnov } \\
\text { test indicates the fact } \\
\text { that the analyzed } \\
\text { distribution is not of a } \\
\text { norrmal type as the } \\
\text { significance coefficient } \\
\text { has a lesser value than } \\
\text { the cut-off value of } 0,05 \text {. } \\
\text { One also needs to } \\
\text { emphasize the fact that } \\
\text { the state shareholding } \\
\text { cannot be found within } \\
\text { the entire group that } \\
\text { was analyzed. }\end{array}$ & $\begin{array}{l}\text { Taking into } \\
\text { consideration the } \\
\text { type of the } \\
\text { present } \\
\text { assymetry, the } \\
\text { normality of the } \\
\text { distribution of the } \\
\text { variable entitled } \\
\text { The presence of } \\
\text { the state in the } \\
\text { shareholding's } \\
\text { structure will be } \\
\text { accomplished } \\
\text { through the } \\
\text { natural In }(\mathrm{x}) \\
\text { logarithm type of } \\
\text { transformation. }\end{array}$ \\
\hline $\begin{array}{l}\text { Based on the histogram } \\
\text { shown herewith, the } \\
\text { variable entitled The } \\
\text { presence of the } \\
\text { individuals in the } \\
\text { shareholding's structure } \\
\text { has a marked positive } \\
\text { assymetry. } \\
\text { The Kolmogorov- } \\
\text { Smirnov test also } \\
\text { indicates the fact that } \\
\text { the analyzed distribution } \\
\text { is not of a normal type } \\
\text { as the significance } \\
\text { coefficient has a lesser } \\
\text { value than the cut-off } \\
\text { value of } 0.05 \text {. }\end{array}$ & $\begin{array}{l}\text { Taking into } \\
\text { consideration the } \\
\text { type of the } \\
\text { present } \\
\text { assymetry, the } \\
\text { normality of the } \\
\text { distribution of the } \\
\text { variable entitled } \\
\text { The presence of } \\
\text { the individuals in } \\
\text { the shareholding's } \\
\text { structure will be } \\
\text { accomplished } \\
\text { through the } \\
\text { natural I }(\mathrm{x}) \\
\text { logarithm type of } \\
\text { transformation. }\end{array}$ \\
\hline
\end{tabular}


Table 5. List of Shareholder Structure Companies

\begin{tabular}{|c|c|c|c|}
\hline No. & State & Legal entities & Individuals \\
\hline 1 & - & 89.9240 & 10.076 \\
\hline 2 & - & 99.0267 & 0.9733 \\
\hline 3 & - & 86.7263 & 13.2737 \\
\hline 4 & - & 70.4193 & 29.5807 \\
\hline 5 & - & 75.5730 & 24.427 \\
\hline 6 & 53.0173 & 33.7720 & 13.2107 \\
\hline 7 & - & 77.7727 & 22.2273 \\
\hline 8 & - & 86.9904 & 13.0096 \\
\hline 9 & - & 74.3294 & 25.6706 \\
\hline 10 & 1.0457 & 82.4127 & 16.5416 \\
\hline 11 & - & 88.2217 & 11.7783 \\
\hline 12 & 58.6882 & 34.7485 & 6.5633 \\
\hline 13 & - & 32.9847 & 67.0153 \\
\hline 14 & - & 92.8569 & 7.1431 \\
\hline 15 & - & 78.0252 & 21.9748 \\
\hline 16 & - & 66.8544 & 33.1456 \\
\hline 17 & - & 90.2494 & 9.7506 \\
\hline 18 & - & 59.5215 & 40.4785 \\
\hline 19 & - & 17.4016 & 82.5984 \\
\hline 20 & - & 81.9550 & 18.045 \\
\hline 21 & 58.7162 & 34.1246 & 7.1592 \\
\hline 22 & - & 2.7242 & 97.2758 \\
\hline 23 & 4.0455 & 95.5393 & 0.4152 \\
\hline 24 & - & 31.1274 & 68.8726 \\
\hline 25 & - & 78.7223 & 21.2777 \\
\hline 26 & - & 67.2560 & 32.744 \\
\hline 27 & - & 67.8583 & 32.1417 \\
\hline 28 & - & 87.8332 & 12.1668 \\
\hline 29 & - & 25.0119 & 74.9881 \\
\hline 30 & - & 9.8362 & 90.1638 \\
\hline 31 & - & 17.4088 & 82.5912 \\
\hline 32 & - & 95.3431 & 4.6569 \\
\hline 33 & - & 87.7895 & 12.2105 \\
\hline 34 & - & 90.3599 & 9.6401 \\
\hline 35 & 59.6222 & 26.4926 & 13.8852 \\
\hline 36 & 54.8062 & 33.8265 & 11.3673 \\
\hline 37 & 20.6389 & 77.5198 & 1.8413 \\
\hline 38 & - & 77.4028 & 22.5972 \\
\hline 39 & - & 96.7804 & 3.2196 \\
\hline 40 & - & 92.4055 & 7.5945 \\
\hline 41 & - & 80.2491 & 19.7509 \\
\hline 42 & - & 93.7301 & 6.2699 \\
\hline 43 & 44.6959 & 54.7319 & 0.5722 \\
\hline 44 & - & 85.9568 & 14.0432 \\
\hline 45 & 0.3313 & 83.4714 & 16.1973 \\
\hline 46 & 81.2705 & 17.3679 & 1.3616 \\
\hline 47 & 70.0071 & 27.7444 & 2.2485 \\
\hline 48 & 58.5097 & 29.9197 & 11.5706 \\
\hline
\end{tabular}


Continued Table 5

\begin{tabular}{|c|c|c|c|}
\hline 49 & - & 91.5129 & 8.4871 \\
\hline 50 & - & 98.6742 & 1.3258 \\
\hline 51 & - & 53.2427 & 46.7573 \\
\hline 52 & - & 60.4428 & 39.5572 \\
\hline 53 & - & 67.5544 & 32.4456 \\
\hline 54 & - & 93.8609 & 6.1391 \\
\hline 55 & - & 44.1525 & 55.8475 \\
\hline 56 & - & 98.0413 & 1.9587 \\
\hline 57 & 3.1715 & 56.0078 & 40.8207 \\
\hline 58 & - & 93.5191 & 6.4809 \\
\hline 59 & 0.0893 & 92.2776 & 7.6331 \\
\hline 60 & - & 46.3955 & 53.6045 \\
\hline 61 & - & 99.1845 & 0.8155 \\
\hline 62 & - & 92.3359 & 7.6641 \\
\hline 63 & - & 68.4262 & 31.5738 \\
\hline 64 & - & 93.8475 & 6.1525 \\
\hline 65 & - & 91.6925 & 8.3075 \\
\hline & $\mathbf{8 . 7 4 8 5 \%}$ & $\mathbf{6 8 . 1 4 5 7 \%}$ & $\mathbf{2 3 . 1 0 5 8 \%}$ \\
\hline
\end{tabular}

After the analysis of the relationships between the scores and the percentage of the institutional shareholding (i.e. individuals in the shareholding's structure), the impact of both the state's and the individuals' presence within the shareholding's structure was statistically analyzed in this section from the point of view of the relationships between the scores corresponding to the quality of the financial and accounting disclosure and the selected indicators. The final results are as follows in Table 6.

Table 6. The univariate analysis of the relationships between the scores and the corresponding percentages for the institutional shareholding and individuals

\begin{tabular}{|c|l|c|c|}
\hline \multirow{2}{*}{\multicolumn{1}{|c|}{ Indicators }} & $\begin{array}{c}\text { Percentage of the } \\
\text { institutional } \\
\text { shareholding }\end{array}$ & $\begin{array}{c}\text { Percentage of } \\
\text { the shareholding } \\
\text { represented by } \\
\text { individuals }\end{array}$ \\
\hline \multirow{2}{*}{$\begin{array}{c}\text { 1st } \\
\text { scoring }\end{array}$} & Pearson index number correlation & 0,488 & $-0,201$ \\
\cline { 2 - 4 } & Significant value & 0,065 & 0,108 \\
\cline { 2 - 4 } & Number of case studies & 15 & 65 \\
\hline \multirow{2}{*}{$\begin{array}{c}\text { 2nd } \\
\text { scoring }\end{array}$} & Pearson index number correlation & 0,079 & $-0,201$ \\
\cline { 2 - 4 } & Significant value & 0,780 & 0,109 \\
\cline { 2 - 4 } & Number of case studies & 15 & 65 \\
\hline \multirow{2}{*}{$\begin{array}{c}3 r d \\
\text { scoring }\end{array}$} & Pearson index number correlation & 0,210 & 0,038 \\
\cline { 2 - 4 } & Significant value & 0,453 & 0,764 \\
\cline { 2 - 4 } & Number of case studies & 15 & 65 \\
\hline \multirow{2}{*}{$\begin{array}{c}4 t h \\
\text { scoring }\end{array}$} & Coeficient de corelaţie Pearson & 0,427 & $-0,148$ \\
\cline { 2 - 4 } & Significant value & 0,112 & 0,238 \\
\cline { 2 - 4 } & Number of case studies & 15 & 65 \\
\hline \multirow{2}{*}{$\begin{array}{c}\text { 5th } \\
\text { scoring }\end{array}$} & Pearson index number correlation & $0,522^{*}$ & $-0,260^{*}$ \\
\cline { 2 - 4 } & Significant value & 0,046 & 0,036 \\
\cline { 2 - 4 } & Number of case studies & 15 & 65 \\
\hline
\end{tabular}


Continued Table 6

\begin{tabular}{|c|l|c|c|}
\hline \multirow{3}{*}{$\begin{array}{c}\text { 6th } \\
\text { scoring }\end{array}$} & Pearson index number correlation & 0,404 & $-0,189$ \\
\cline { 2 - 4 } & Significant value & 0,136 & 0,131 \\
\cline { 2 - 4 } & Number of case studies & 15 & 65 \\
\hline \multirow{2}{*}{$\begin{array}{c}\text { Total } \\
\text { scoring }\end{array}$} & Pearson index number correlation & 0,459 & $-0,233$ \\
\cline { 2 - 4 } & Significant number & 0,086 & 0,062 \\
\cline { 2 - 4 } & Number of case studies & 15 & 65 \\
\hline
\end{tabular}

Source: personal interpretation based on the data processed in SPSS v.22.

In regards to the analyzed relationships between the percentages corresponding to the state shareholding and the ones corresponding to the individual shareholding, significant common points have been noticed from a statistical point of view just for the 5th intermediate case study corresponding to the forecast and prospective information.

As far as the percentage of the institutional shareholding is concerned, statistically speaking there is a significant relationship (the significance value is less than the threshold value of 0,05 ) between the positive, average $(r=0,522)$ with the scoring afferent to the previsional information and the indicators that describe the size of the companies. This is part of the initial assumption. Moreover, on the 5th scoring the initial assumption is valid in regards to the percentage of the individuals as stakeholders. There is an inverted relationship of a weak intensity $(r=-0,260)$, yet a significant one from a statistical point of view.

We also need to observe the fact that the 1 st and the 2 nd assumptions are true only for the score that corresponds to the previsional and prospective information. Generally speaking, we can conclude that the 1 st and the 2 nd assumptions have been invalidated. The graphical representation of the shareholding's influence on the structure of the quality of the financial and accounting disclosure has been done by using the correlograms that illustrate the difference between the total scoring and the shareholding's structure. A presentation and interpretation of these correlograms are given below.

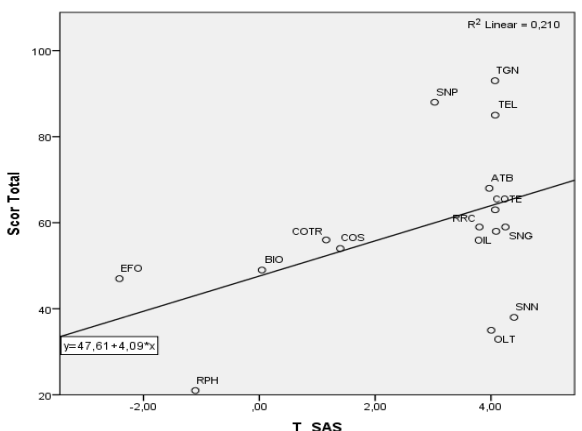

Figure 9. The correlogram of the relationship between the total scoring and the percentage of the institutional shareholding

Source: personal interpretation based on the data that were processed in SPSS v. 22

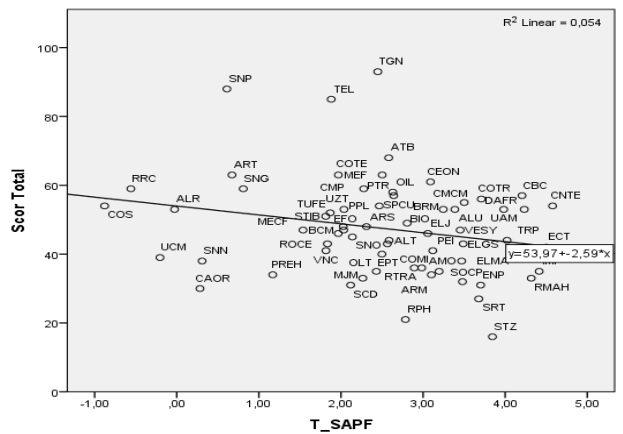

Figure 10. The correlogram of the relationship between the total scoring and the percentage of the shareholding as individuals

Source: personal interpretation based on the data that were processed in SPSS v.22.

The correlogram (Figure 9) that corresponds to the relationship that exists between the total scoring of the financial and the quality of the financial and accounting disclosure and the percentage of the institutional shareholding emphasize a relative grouping of the case studies around a regression index. 
The value of the $R^{2}=0,210$ determinant coefficient indicates that the variation of the percentage of the institutional shareholding explains a $21,0 \%$ out of the variation of the total scoring.

The correlogram (Figure 10) that corresponds to the relationship that exists between the total scoring of the financial and accounting disclosure and the percentage of the individuals within the shareholding emphasize a weak grouping of the analyzed case studies around a regression index. The value of the $R^{2}=0,054$ determinant coefficient indicates that the variation of the percentage of the shareholding as individuals explains a $5,4 \%$ out of the variation of the total scoring.

In conclusion, we can state that both the presence of the institutional shareholding and that of the shareholding as individuals do not exert an influence on the quality of the financial and accounting disclosure of the companies' that were analyzed. Both research assumptions that were formulated regarding this issue are not valid after they have previously been tested by using the unvariate analysis.

Conclusions. As a conclusion, we can state the fact that the economic and financial communication needs to make improvements in terms of the informational transparency that is a key element for building up its credibility. The interest on a transparent disclosure has become a key element for the improvement in terms of gaining the trust of the stakeholders. This situation may inevitably lead to paying closer attention to the stakeholders' specific demands that are sometimes represented by small niches that can stand for the interests of just a single individual. Consequently, a new approach to the market needs to be done. It does not strictly result from the tradition of the marketing itself, yet it needs to refer to the proactive role of the stakeholders in defining the company's strategy. Even if the study's practical examples focussed only on the stakeholders' demands, the quality of the economic and financial disclosure requires that the supplied information has all those features that characterize highquality information, that is the must be relevant and precise, easy to understand, timely, comparable and verifiable. The lack of these features, no matter the specific type of stakeholders, will give rise to suspicions in the existing relationships, it will have a negative effect on the company's image and credibility and ultimately its direct effects will influence the overall value of the reporting company. The results of the study may be useful to the stakeholders, the business environment, the financial-banking institutions, the state, highlighting the importance, need and benefits of a qualitative economic and financial communication in the decision-making process.

Author Contributions: conceptualization M. C.; data curation, M. S. methodology, M. C. and M. S.; supervision, D. S.; M. C.; investigation, S. M., and M. S.; formal analysis, D. S. and S. M.; validation, M. C. and M. S.; visualization, M.C. and M.S.; writing-original draft preparation, M.C. and M. S.; writing review and editing, D. S. and M. C.

Funding: This work is supported by project POCU 125040, entitled "Development of the tertiary university education to support the economic growth - PROGRESSIO", co-financed by the European Social Fund under the Human Capital Operational Program 2014-2020.

\section{References}

Adhikari, A., \& Tondkar, R.H. (1992). Environmental factors influencing accounting disclosure requirements of global stock exchangs. Journal of International Financial Management and Accounting, 4(2), 75-105 [in English]

Anthony, R.N., Hawkins, D.F., Macri, D.M., \& Merchant, K.A. (2005), Accounting (Italian edition), Mc Graw- Hill, Milano, Italy. [in English]

Bocchini, E. (2001). Introduzione al dirittocommercialenella new econom [Introduction to commercial law in the new economy], Cedam, Padova. [in Italian]

Bostan, I., Grosu, V., lancu, E. (2009). The role and importance of economic and financial information in corporate governance, AnnalesUniversitatisApulensis Series Oeconomica, 11(1), 163- 169. [in English]

Bunget, O.C., Blidisel, R.G., Feleaga, L., Popa, I.E. (2014). Empirical Study of Intangible Assets in Romanian Municipalities, Ekonomie a Management, 17(3), 136-150. [in Romanian]

Burciu, A, \& Kicsi, R. (2015). Knowledge as a distinctive resource of competitive advantage Ecoforum Journal, 4, 9-14. [in 
English]

Cocozza, A. (2012). Comunicazione d'impresa e gestione delle risorse umane. Valorizzare le persone nelle imprese innovative e nelle pubbliche amministrazioni virtuose [Business communication and human resources management. Valuing people in innovative companies and in virtuous public administrations], Milano: Franco Angelieditore. [in Italian]

Corvi, E. (2000). Comunicazione d'impresa e investor relation: la gestione della comunicazione economico-finanziaria [Business communication and investor relations: the management of economic and financial communication], Editore Egea, Milano. [in Italian]

Corvi, E. (2007). La comunicazione aziendale: obiettivi, tecniche, strumenti [Corporate communication: objectives, techniques, tools], Egea ED. Milano. [in Italian]

Cosmulese, C.G. (2015). Difficultes et limitesdans la reconnaissance et l'evaluation des actifs intangibles conformement aux standards nationals et internationals [Difficulties and limitations in the recognition and evaluation of intangible assets in accordance with national and international standards], Revue Valaqued' Etudes Economique, Faculte des Sciences Economiques, Universite Valahia de Targovişte, Volume 6(20), No. 3, 25-34. Retrieved from http://www.rvee.eu/images/2015/no3/5.rvee\%20vol.6\%2020\% 20no.3\%202015\%20-\%20leliuc.pdf; [in French]

Cosmulese, C.G. (2017). Comparative studies on the disclosure of information about intellectual capital in financial reports of entities in different parts of the world, Prospects of accounting development: the young researcher's view, 22 November, Chișinau, ASEM, 45-53, ISBN 978-9975-75-895-6, Retrieved from http://ase.md/files/catedre/cae/conf/conf_con_22.11.17.pdf. [in English]

Cosmulese, C.G., Mateș, D., Anisie, L. (2016). Particulars on approaches and methods used to value intangibles assets, Management Strategies Anul IX, nr. IV (34), Pitești, 28-39, Retrieved from http://www.strategiimanageriale.ro/images/images_site/ articole/article_4dbde7270dce04b2682a47df 0abe79c5.pdf [in English]

Cuervo, A. (2002). Corporate Governance Mechanisms: A Plea for Less Code of Good Governance and More Market Control. Corporate Governance, 10(2), 84-93. Retrieved from https://onlinelibrary.wiley.com/doi/epdf/10.1111/1467-8683.00272

Di Gaspare, G. (2011). Teoria e Critica della globalizzazione finanziaria, Dinamiche di potere finanziario e crisi sistemiche [Theory and Criticism of Financial Globalization, Dynamics of Financial Power and Systemic Crises], CEDAM, Milano. [in Italian]

Djoko, S. (1992). An Empirical Investigation of the Extent of Corporate Disclosure. Annual Reports of Companies Listed on the Jakarta Stock Exchange, PhD thesis, University of Arkansas. [in English]

El-Issa, Y. (1988). The usefulness of corporate financial disclosure to investors in Amman financial market. Unpublished PhD Thesis. Lancaster University, UK. [in English]

Fiocca, R. (2002).L'impresa: un insieme (organizzato) di persone che comunica [The company: an (organized) group of people who communicate], Journal Sinergie rivista di studi e ricerche, 59. [in Italian]

Grosu, V. (2010). Trends and Limitations in the Economic and Financial Harmonization,Tipo Moldova Editor, lasi, 25-72. [in English]

Grosu, V. (2013). Evaluation the Intellectual Capital. Studies and Researches on the Impact of the Research and Innovation on the Economic Progress, 4th volume, Post-Doctoral Studies in Economics- Post-Doctoral Dissertations in Economy, Romanian Academy edition, Bucharest. [in English]

Ho, S.S. \& Wong, K.S. (2001). Study of the Relationship between Corporate Governance Structure and the Extent of Voluntary Disclosure. Journal of International Accounting, Auditing and Taxation, 10, 139-156. [in English]

Itami, H. (1988). Le risorseinvisibili [The invisible resources], Torino, Isedi. [in Italian]

Jetty J., Beattie V., Charity Reporting - A Study of Disclosure Practices and Policies of UK Charities, Association of Chartered Certified Accountants, 2009. [in English]

Kassarjian, H.H. (1977). Content Analysis in Consumer Research, Journal of Consumer Research, 4, 8-18. [in English]

Labelle, R. \& Schatt, A. (2005). Structure de proprieteet communication financiere des entreprisesfrancaices [Property structure and financial communication of French companies], Finance CotroleStrategie, 8(3), 77-104. [in French]

Lacchini, M. (2002). Modelli di Corporate governance e bilanci d'impresa nella prospettiva della riforma [Corporate governance models and corporate balance sheets in the perspective of reform], Giappichelli, Torino [in Italian]

Mancini, D., Lamboglia, R. (2005). II sistema informativo aziendale: aspetti definitori e requisiti di efficacia [in Italian], Universita di Napoli Parthenope. [in Italian]

Marchi, L. (1993). I sistemi informative aziendale [Company information systems], Giuffrè, Milano. [in Italian]

Marston, C.L., \& Shrives P.J. (1991). The Use of Disclosure Indices in Accounting Research: A Review Article, in The British Accounting Review, 23, 195-210. [in English]

Monteduro, F., \& Salerno, I. (2011). II sistema informativo aziendale e la contabilita direzionale [The company information system and management accounting], Economia Aziendale, lezione 8, a course delivered at Universita degli Studi di Roma Tor Vergata. [in Italian]

Mot, I., Mateș, D., Grosu, V., \& Domil, A. (2014). The Financial Reporting on the Level of SMES. Internationalization and Applicability, TheEuropean Journal of Accounting, Finance \& Business, 2(1), 23-33. [in English]

Naidoo, R. (2002). Corporate Governance: An Essential Guide for South African Companies, Double Storey, Cape Town. [in English]

Nastase, C., Casovschi, C., Popescu, M., \& Scutariu, L. (2010).The Importance of Stakeholders and Policy Influence Enhancing the Innovation in Nature Based Tourism Services Greece, Austria, Finland and Romania Case Studies, European 
Research Studies Journal XIII(2), 137-148. [in English]

Pastore, A., \& Vernuccio, M. (2008). Impresa e comunucazione. Principi e strumenti per il management [Business and communication. Principles and tools for management], Seconda edizione, Socio Unico Giangiacomo Feltrinelli Editore s.r.l., Milano, Italy [in Italian]

Poggio, G., Zaccone, D., \& Bianchi, S. (2003). La comunicazione ai mercati finanziari in un confronto internazionale [Communication to financial markets in an international comparison], Amministrazione e Finanza, 18(23), 56-62. [in Italian]

Rordorf, R. (2002). I controlli. Verso il nuovo diritto societario. Dubbiedattese [The controls. Towards the new company law. Doubts and expectations], November 12th, Florenţa. [in Italian]

Salvioni, D. (2002). Cultura della transparenza e comunicazione economico-finanziaria d'impresa, ISTEI Universita degli Studi di Milano - Bicocca. [in Italian]

Spaventa, L. (2002). Struttura proprietaria e corporate governance. Ai confini tra diritto ed economia . [Ownership structure and corporate governance. On the border between law and economy], UniversitadegliStudi di Macerito, LaboratoriaFaustaVicarelli. [in Italian]

Van Riel, C.B.M., \&Fombrun, C.J. (2007) Essentials of Corporate Communication: Implementing Practices for Effective Reputation Management, Routledge Publisher, London. [in English]

Чоботару Маріус, Ph.D., Сучавський університет імені Штефана чел Маре (Румунія);

Соколюк Маріан, Ph.D., Сучавський університет імені Штефана чел Маре (Румунія);

Міхайла Світлана, Ph.D., доцент, Академія економічних досліджень Молдови (Республіка Молдова);

Савчук Дмитро, к.е.н., доцент, Чернівецький національний університет імені Юрія Федьковича (Україна).

Імідж компаній: маркетингові і фінансові комунікації

Основною метою дослідження $\epsilon$ оцінка якості економічних та фінансових даних з точки зору задоволення вимог акціонерів, а також впливу, який структура акцій може мати на економічну та фінансову інформаційну систему компанії. Підставами для теоретичної підготовки були систематичний огляд та критичний аналіз літератури з області дослідження. Згідно з результатами дослідження літератури, були розроблені зв'язки між областями дослідження та гіпотезою взаємозв'язку між статусом держави, як зацікавленої сторони, та якістю інформації, яка була опублікована в щорічних звітах. Аналізована вибірка спочатку складалася з тих компаній (105), які були зареєстровані на фондовій біржі Бухареста, тоді як метод оцінки якості розкриття інформації базувався на методі скорингу, тобто на балах, що надаються класифікованим елементам, характер простих або похідних показників. Після застосування критеріїв включення виключення залишилося лише 65 компаній. Об'єктом дослідження $\varepsilon$ компанії, які готують свої фінансові звіти з використанням МСФЗ (Міжнародні стандарти фінансової звітності). Основним джерелом інформації були щорічні або проміжні опубліковані фінансові звіти. Ця стаття показує, що економічні та фінансові комунікації повинні покращувати інформаційну прозорість, що є ключовим елементом для підвищення достовірності. Навіть якщо практичні приклади дослідження зосереджені лише на вимогах зацікавлених сторін, якість економічного та фінансового розкриття вимагає, щоб надана інформація мала всі ті особливості, які характеризують високоякісну інформацію, тобто вона повинна бути актуальною та точною, легко зрозумілою, своєчасною, порівняною і перевіреною. Важливість цього дослідження випливає з того факту, що одержувачі фінансової інформації стають все більш і більш зацікавленими в якості останньої, характеристиці, яка по суті є основою ї рішень стосовно суб'єкта господарювання, що звітує. Результати дослідження можуть бути корисними для зацікавлених сторін, бізнес-середовища, фінансово-банківських установ, держави, підкреслюючи важливість, потребу та переваги якісної економічної та фінансової комунікації в процесі прийняття рішень.

Ключові слова: оцінка, прості та похідні показники, структура акціонерного капіталу, фінансово-економічна інформація, якість.

Manuscript received: 03.07.2019

(c) The author(s) 2019. This article is published with open access at Sumy State University. 